\title{
nature
}

30 August 2001 Volume 412 Issue no 6850

\section{Decision time at Yucca Mountain}

The United States should only proceed with its sole proposed nuclear-waste repository once geological concerns have been addressed and provided that law-makers are convinced that the assessment process has been conducted fairly.

$\mathrm{T}$ his time it is for real: after years of investigation and prevarication, the US government will soon decide whether it can safely bury spent nuclear fuel and other nuclear waste at a planned repository under Yucca Mountain in Nevada. The decision is the culmination of a vast 20-year exercise to characterize the proposed site and assess its associated risks (see News Feature, page 850).

The nuclear power industry in the United States currently stores most of its spent fuel on the surface, at or near nuclear power stations. The US Department of Energy (DOE) is legally obliged to take the spent fuel and so is under intense pressure to proceed with the Yucca Mountain project - currently the United States' only option for long-term disposal.

The decision on whether to proceed with Yucca Mountain has been a long time coming. Sceptics doubt if 20 years of study at a cost of some $\$ 7$ billion has really been necessary to establish the project's viability and safety. But if the outcome of the process is some measure of public acceptance for the project - not least in Nevada - then the wait will have been worthwhile. Indeed, an argument can be made that the government has not yet waited long enough.

The Yucca Mountain project began its tortured existence in an era when public demands for accountability in science-based decisionmaking were far less onerous than they are today. In those far-off days of the 1970s and early 1980s, the DOE was a cold-war autocracy whose apparatchiks saw little need for consultation either with the general public or with technical advisers from outside its own ranks.

But times have changed since then, and an excellent and timely report (Disposition of High-Level Waste and Spent Nuclear Fuel: The Continuing Societal and Technical Challenges - see http://www. nap.edu) released earlier this year by the US National Research Council (NRC) describes what the changes mean for nuclear-waste disposal. The report notes that no nation has yet succeeded in building a permanent store for spent fuel or other highly radioactive waste.

The approach recommended by the NRC's report rests on two pillars: complete openness with the public, and external scientific peer review. The Yucca Mountain process has been strong in the former, at least lately, but weak in the latter. It has been far too reliant on the expertise of the DOE's own laboratories, and not insistent enough on publishing its findings in the scientific literature or on reaching out to experts in the universities and elsewhere. For example, recent work by outside experts on lava flow suggests possible shortcomings in the models that the DOE has used to predict the integrity of the repository in the event of volcanic activity at the mountain.

In the past few years, the project has been gradually evolving in these directions. It has appointed an international panel to review its work, for example - although the panel will not report until after the United States has passed its critical decision point. President George $\mathrm{W}$. Bush is expected to announce his own decision on the matter by the end of the year. It is likely that, armed with a recommendation from the DOE that the site is suitable, he will say the project should proceed. The state of Nevada is then entitled to declare its opposition to the project, and is certain to do so. Finally, under a special law, it will fall to both houses of Congress to vote the project up or down, probably in early 2002.

There is a natural tendency for the technically minded to root for projects such as Yucca Mountain to succeed. Many of those who have been involved in nuclear science and engineering feel that their work is somehow tarnished if a technical problem, such as the safe disposal of spent nuclear fuel, cannot be fixed.

But the paramount considerations must be that the solution is safe and, just as importantly, that the process by which it is derived has been fair. The project should proceed only if the DOE can establish both points.

\section{Women worse off (cont.)}

The California Institute of Technology needs to address imbalances and frustrations.

W ith a growing number of women students, and situated in the state that sees itself as America's most progressive, the California Institute of Technology would seem to be an ideal arena to nurture a research community free of gender warfare. But a study reported in this issue (see page 844 ) shows deep dissatisfaction among the one in ten of Caltech's faculty who are women. The women feel — and the facts suggest — that they have had an anomalously high chance of being spurned when leadership positions were filled; they feel discriminated against by administrators who dole out endowed chairs, which underwrite salaries; and they have now learned that they are paid less for equal work.

The intense atmosphere has led to backbiting. A senior woman faculty's reticence to fight for equal salaries was called "traitorous" by another woman professor. Women faculty who push for their rights were called "young hotheads" by senior faculty. And there is lingering bitterness among the senior and junior faculty women over battle tactics in the gender war. All this in a state where women have increasingly assumed leadership positions in the corporate and political world.

This past spring, Caltech elected the first woman 'chair' of the faculty. Last winter, the biology division saw its first woman faculty member receive an endowed chair, after some $70 \%$ of male biology faculty already had endowments. But the woman biologist's endowment came only after strong lobbying.

As a private university, the onus for improvement rests with Caltech's administration and board of trustees. Its president, David Baltimore, is lauded by a number of women faculty for his leadership and open-door policy of listening to all faculty. Ensuring that women have an equal voice in leadership and committees, bestowing endowments in a way that is demonstrably fair, and giving women equitable salaries would be three major steps forward. 